\title{
Islamic Screening Mechanism of Islamic Capital Market-A Comparison Between the Fatwa-DSN-MUI, the Kuala Lumpur Stock Exchange Islamic Index and the Dow Jones Islamic Market Index
}

\section{Atina Shofawati}

Islamic Economics Department, Faculty of Economics and Business, Universitas Airlangga

\section{Abstract}

Globally, the role of capital market is very essential. Capital market is the source of capital for a firm. According to the theory of capital structure, Pecking Order Theory, which emphasizes the hierarchy of financing, stock in capital market is the last choice for firm financing if the internal financing hasn't sufficient funds for the operational

Corresponding Author: Atina Shofawati atinashofawati@yahoo.com

Received: 29 August 2018 Accepted: 18 September 2018 Published: 11 November 2018

Publishing services provided by Knowledge

(c) Atina Shofawati. This article is distributed under the terms of the Creative Commons

Attribution License, which permits unrestricted use and redistribution provided that the original author and source are credited.

Selection and Peer-review under the responsibility of the ICOI-2018 Conference Committee.

\section{G OPEN ACCESS} activity of the firm. The existence of the Islamic capital market is very important because of the increasing Islamic business in the world. In Indonesia and in the world in general, Islamic product is only available in the conventional capital market, so it is necessary to decide the mechanism of screening the stock in the Islamic capital market to obtain the product of Islamic capital market according to sharia compliance. This study will compare the mechanism of stock screening according to the Fatwa DSN-MUI, the Kuala Lumpur Stock Exchange Islamic Index, and the Dow Jones Islamic Market Index. This study uses qualitative method. The result of the study gives the explanation of the mechanism of stock screening in the Islamic capital market based on the Fatwa DSN-MUI, the Kuala Lumpur Stock Exchange Islamic Index, and the Dow Jones Islamic Market Index and their role for the development of the Islamic capital market.

Keywords: Islamic screening, capital market, Fatwa DSN-MUI, the Kuala Lumpur Stock Exchange Islamic Index, Dow Jones Islamic Market Index

\section{Introduction}

Nowadays, Muslim society has a strong religiosity which has implications for the implementation of Islamic value in every life system, including muamalah Maliyah (economic activity). Therefore, the availability the instrument of Islamic finance, banking and investment is essential in Muslim society to meet its economic activity according to sharia compliance. Besides that, in Islamic financial institutions such as banking, the capital market needs the customer to become the market of their product or services. The development of Muslim society in the world shows an increase in both quality and 
quantity. The world's large Muslim population show that there is a captive market for the development of Islamic financial institutions.

Government has developed some regulations to develop the Islamic Capital Market, while the National Sharia Council has developed a fatwa which is related to transactions in the capital market. The Indonesian Capital Market uses Islamic investment screening according to the National Sharia Council (DSN) Indonesia and most capital markets in many countries in the world use Islamic screening according to the Sharia Council of Dow Jones Islamic Market (DJIM) Index. Based on Islamic screening in the capital market, the development of the Islamic capital market can grow rapidly in the world and ensure the transaction in capital market compliance with Islamic Law to attain a universal vision of Islamic business, that is al Folah, which is the happiness of the world and the hereafter (Shofawati, 2011).

The need to screen a stock before making investment is derived from Sharia principles that Muslims should never participate in any activity, investment, or noninvestment, which is prohibited by Sharia. In the equity investment world, Shariacompliant investments can be considered along the lines of socially-responsible investments (SRI) or ethical investments, in which stocks are screened on certain qualitative and quantitative criteria before selection is made. The screening process, therefore, narrows down the number of eligible stocks for investment, thus resulting in a fewer number of stocks available to form an efficient portfolio. In other words, the benefits from diversification may not be maximized by the ethical investors. Based on this notion, the general perception of ethical investment and Sharia investment is that ethical or Sharia-compliant investors may earn lower returns than the unscreened portfolios or market benchmarks (Engkuchik, 2016).

The availability of Islamic stock screening is needed to encourage the development of the Islamic Capital Market. This study emphasizes the mechanism of Islamic stock screening according to the Fatwa DSN-MUI, the Kuala Lumpur Stock Exchange Islamic Index and the Dow Jones Islamic Market Index

The Dow Jones Islamic Market ${ }^{T M}$ Index series includes thousands of broad-market, blue-chip, fixed-income and strategy and thematic indices that have passed rulesbased screens for Sharia compliance. Launched in 1999, DJIM World was the world's first global Sharia-compliant benchmark. Compliance concerns Muslim investors who would otherwise face difficulties in constructing Islamic investment portfolios. To determine their eligibility for the indices, stocks are screened to ensure that they meet the standards set out in the published methodology. Companies must meet Sharia requirements for acceptable products, business activities, debt levels and 
interest income and expenses. The screening methodology is subject to input from an independent Sharia supervisory board. By screening stocks for consistency with Sharia law, the indices help to reduce research costs and compliance concerns Muslim investors would otherwise face problems in constructing Islamic investment portfolios (https://us.spindices.com)

The Kuala Lumpur Stock Exchange Sharia Index (KLSE SI) is a stock market indicator for the performance of the sharia-approved securities on the exchange. The index was introduced on the 17 of April 1999. Its components consist of all the sharia-approved securities listed on the Main Board. The sharia-approved securities lists are updated or revised twice a year, that is the last Friday of April and October when the list is released by the Sharia Advisory Council (SAC), a special body formed by the Securities Commission. The SAC applies standard criteria in classifying these so-called shariaapproved securities. The focus of the criteria is on the core business activities of the companies (Ahmad \& Ibrahm, 2002).

In Indonesia, Islamic screening of stock is in accordance with Fatwa Dewan Syari'ah Nasional NO: 40/DSN-MUI/X/2003 about capital market and general guidelines for the application of sharia principles in the field of capital market

Due to the different measures used of Indonesian and international indices, this study will describe the similarity and difference in screening indices used for the Sharia compliant firms between screening mechanism of DSN MUI in Indonesia in comparison to the International Indices, Dow-Jones Islamic World Market (DJIM) and the Kuala Lumpur Stock Exchange Sharia Index (KLSE SI). This article reviews the Islamic Screening Mechanism of the Islamic Capital Market by Fatwa DSN-MUI and the Dow Jones Islamic Market Index and the Kuala Lumpur Stock Exchange Sharia Index (KLSE SI).

\section{Literature Review}

The term investment can cover a wide range of activities; it is generally referred to investing money in certificates of deposit, bonds or common stocks. An investment can be defined as the commitment of funds to one or more assets that will be held over some future time period in order to gain future value by sacrificing the present value of asset (Mayo, 2011 as cited in Htay et al., 2013; Muhammad, 2005). Islamic principles do not permit unbridled pursuit of self-interest that results in a zero sum game in which the gain of one is always at the expense of the other. Hence, transactions involving 'Gharar' and 'Zarar' are also not allowed (Shaikh, 2010). 


\subsection{Islamic screening mechanism of the Islamic capital market}

Sharia stock screening process represents the process of identifying Sharia-compliant equity investments incorporating certain compromise or tolerance. In general, several major elements are typically addressed when performing Sharia screening of shares, which include business activity or sector screening, debt financing or leverage screening, interest-based revenue screening, and dividend or income purification screening (Engkuchik, 2016). Currently, there is an absence of international Sharia standard for equity screening (Jamal et al., 2010 as cited in Engkuchik, 2016). Therefore, different Sharia index providers or different Islamic equity funds have set up their own Sharia advisory committees to formulate the Sharia screening criteria, which tend to be slightly different from one another. One of the major issues resulting from the nonunification of Sharia screening criteria is when a company's core business is permissible, but, at the same time, it is also involved in some prohibited business (Jamal et al., 2010 as cited in Engkuchik, 2016). Thus, stocks are distributed worldwide and different indices would be used to determine whether these stocks comply with sharia, depending upon the country of stock issuance (Wan Zainal et al., 2016).

\subsection{Islamic screening investment according to Fatwa DSN-MUI}

Islamic Screening Investment according to Fatwa DSN MUI is based on FATWA DEWAN SYARI'AH NASIONAL NO: 40/DSN-MUI/X/2003 about the capital market and general guidelines for the application of sharia principles in the field of capital market. Chapter 5 about securities transaction, Article 5 about forbidden transaction:1. The implementation of the transaction must be done according to the principle of prudence and not allowed to speculate and manipulation which contains elements of dharar, gharar, riba, maisir, risywah, maksiat and kezhaliman; 2. Transactions containing elements of dharar, gharar, riba, maisir, risywah, maksiat and kezhaliman as referred to verse 1 include: a. Najsy, that is, to make a false offer; b. Bai 'al-ma'dum, that is, selling the goods (Sharia Securities) that have not been owned (short selling); Insider trading, that is, using inside information to gain profit on forbidden transactions; $d$. Cause misleading information; e. Margin trading, which is transactions on the Sharia Securities with an interest-based loan facility on the settlement of such Sharia Securities purchases; $\mathrm{g}$. Ihtikar (hoarding), which is to purchase or collect a Sharia Securities to cause a change in the price of the Sharia Securities, in order to influence the other Party; and h. Other transactions containing the aforementioned elements. 


\subsection{Islamic screening investment according to the Kuala Lumpur stock exchange islamic index}

In Malaysia, the Securities Commission (SC) introduced the Kuala Lumpur Stock Exchange Sharia Index (KLSESI) in 1997 as a vital mechanism in order to accelerate the achievement of an Islamic capital market (ICM) plan. The ICM refers to the market where activities are carried out in ways that do not conflict with the conscience of Muslims and the religion of Islam. In other words, the ICM represents an assertion of religious law in capital market transactions where the market should be freed from the involvement of prohibited activities by Islam, such as usury (riba), gambling (maisir) and ambiguity (gharar) (Securities Commission, 2002 as cited in Rahman et al., 2010).

\subsection{Islamic screening investment according to the Dow Jones islamic index}

The Dow Jones Islamic Indices represent global Sharia-compliant indices which are classified under four main categories, that is, The Blue Chip Indices (e.g., Dow Jones Islamic Market Asia/Pacific Titans 25 Index, Dow Jones Islamic Market U.S. Titans 50 Index, and Dow Jones Islamic Market International Titans 100 Index); the Broad Market Indices (e.g., Dow Jones Islamic Market Emerging Markets Index, Dow Jones Islamic Market Europe Index, and Dow Jones Islamic Market GCC Index); the Fixed Income Indices (e.g., Dow Jones Sukuk Index); and the Strategy and Thematic Indices (e.g., Dow Jones Islamic Market BRC Index, Dow Jones Islamic Market and Global Finance and Takaful Index, and the Dow Jones Islamic Market Sustainability Index). Each index represents stocks and fixed income investments from global markets which have been screened for their Sharia compliance. By screening stocks for consistency with Sharia principles, the indices help to reduce research costs and compliance concerns for Muslim investors who wish to participate in stock investments around the world (Engkuchik, 2016).

\section{Method}

This study uses descriptive qualitative method in nature. It compares the Islamic screening mechanism of the Islamic capital market between the Fatwa DSN-MUI, the Kuala Lumpur Stock Exchange Islamic Index and the Dow Jones Islamic Market Index. Data were collected based on literature study from journals and regulators consisting of Fatwa Dewan Syari'ah Nasional No: 40/DSN-MUI/X/2003 about the capital market 
and general guidelines for the application of sharia principles in the field of the capital market and Regulation Number II.K.1: Criteria And Publishing Sharia Securities List, Number: Kep-180/BL/2009, 30 June, 2009.

\section{Results and Discussion}

Fatwa Dewan Syari'ah Nasional No: 40/DSN-MUI/X/2003 in Chapter 3 about Emitents Publishing Sharia Securities, Article 3 about criteria of issuers or public companies: 1. Types of business, goods, services and contracts and the management of an issuer or a public company issuing sharia securities may not be in conflict with the sharia principles; 2 . Types of business activities that are contrary to sharia principles as referred to in Article 3 number 1, among others: a. Gambling and games belonging to gambling or forbidding trade; b. Conventional financial institutions (ribawi), including conventional banking and insurance; c. Illicit producers, distributors and food and beverage traders; d. Producers, distributors, and/or providers of goods or services that undermine morals and are harmful; e. Investing in issuers (companies) in which, at the time, the transaction (level) of the company's debt to the financial institution of ribawi is more dominant than its capital; 3. An issuer or public company intending to issue sharia securities is required to sign and comply with sharia-compliant contracts on sharia securities issued; 4. An issuer or public company issuing sharia securities shall ensure that its business activities comply with the sharia principles and have a sharia compliance officer; 5 . In the event that the issuer or public company issuing sharia securities at any time does not meet the aforementioned requirements, then securities issued by itself are not as sharia securities.

The Sharia Advisory Council (SAC) of KLSESI and other indices have adopted a similar view on the core activities of a company that does not contravene the Sharia as the general principle in determining whether the company could be or could not be included in the index. However, each index uses different additional criteria in determining a permissible company. For example, the Dow Jones Islamic Market Index (DJIM) uses three additional financial characteristics, that is, level of debt, level of liquidity and level of interest income as compulsory criteria during the screening process for prospective companies. The SAC of KLSESI, in its written guidelines, focuses only on two criteria, namely: (1) core activity; and (2) level of interest income of company to determine whether a particular company is permissible or not in its index. However, it is silent on the other two criteria, namely: (1) the debt level; and (2) liquidity level as used by other Islamic Indices (Rahman et al., 2010). According to Wan Zainal et al. 
(2016), SAC Revised 2013 consists of: 1. Business activity is core business (tolerate minor violations, as long as the core business is permissible); 2 . Liquidity Ratio $<33 \%$ of: Cash and Cash Equivalent/Total Assets; 3. Debt Ratio is < $33 \%$ of: Total Debt/Total Assets.

KLSESI, as an important product of the ICM, was introduced in 1997 in order to provide an avenue for Muslim investors to participate in equity investments in accordance to Sharia principles. This index comprised of firms listed on both the Main and the Second Board, and Masdeq at KLSE (at present known as Bursa Malaysia). As of 26 October, 2006, 642 companies out of 811 companies listed on the aforementioned three boards were approved by the SAC of the SC as permissible securities. According to the SC, the SAC has applied standard criteria as guidelines in determining whether the core activities of the companies listed on KLSE (before approving such company) are permissible for investment under the Sharia law. The activities are considered impermissible if: (1) Operations are based on riba (interest), such as activities of financial institutions like commercial and merchant banks, and finance companies; (2) Operations involve gambling; (3) Activities involve the manufacture and/or sale of haram products, such as liquor, pork and meat not slaughtered according to Islam; (4) Operations contain elements of gharar (uncertainty), such as conventional insurance companies. For companies whose activities comprise of both permissible and nonpermissible elements, the SAC has set out several additional criteria, as follows: (5) The core activities of the companies must not contravene the principles of Sharia as outlined in the aforementioned four criteria. Furthermore, the proportion of unlawful (haram) elements must be very small compared with the core activities; (6) The public perception or image of the company must be good; (7) The core activities of the company are important and considered maslahah (benefit in general) to the Muslim Ummah and the country, while the haram (unlawful) element is very small and involves matters such as ummu balwa (common plight), uruf (custom) and the rights of the non-Muslim community which are accepted by Islam; (8) The level of interest income received from fixed deposits in conventional financial institutions and other investments in interest-bearing accounts complies with the levels set up by the SAC (Rahman et al., 2010).

The DJIM filters a prospective company's eligibility (after removing companies with unacceptable primary business activities) based on compliance with three financial ratios, namely: (1) Companies must have a debt to equity ratio equal to or less than $33 \%$. (2) Companies must have an accounts receivable to total asset ratio equal to or 
less than $47 \%$. (3) Companies must not receive more than $9 \%$ of total income from non-operating interest activities (Rahman et al., 2010).

Islamic indices which cover DSN-MUI, KLSESI and DJIM for screening of stock have similarities and differences. The similarity of each index is that they conduct screening based on two criteria, business screening criteria and financial screening criteria, but the differences among the indices are especially from the financial screening criteria specification. According to the FATWA DEWAN SYARI'AH NASIONAL NO: 40/DSN$\mathrm{MUI} / \mathrm{X} / 2003$, financial criteria was reflected in "investing in Issuers (companies) that at the time the transaction (level) of the company's debt to the financial institution of ribawi is more dominant than its capital." According to Regulation Number II.K.1: Criteria And Publishing Sharia Securities List, Number: Kep-180/BL/2009, 30 June, 2009, the criteria and publishing sharia securities must meet the following financial ratios:(1) total interest-based debt compared to total equity of not more than 82\%(eighty-two per one hundred); (2) total interest income and other unlawful income compared to the total earning of business (revenue) and other income not more than $10 \%$. According to Rahman et al. (2010), it is evident that one of the main reasons why the differences exist among Islamic Indices is due to micro-factors as faced by Malaysian companies. Capital resources are very limited in Malaysia and other countries in this region as compared to Arabian countries where institutions and individuals form the major capital providers. Thus, companies in the latter countries will prefer an equity approach to finance their capital. The existing practice in determining the rules to be used by each index lies fully on the Sharia supervisory board of the respective indices. As a result, the indices will differ from one country to another.

Dow Jones begins the screening process by eliminating companies which are involved in any of the following business activities or products, which include alcohol, pork-related products, conventional financial services such as banks and insurance companies, entertainment business such as cinema and music production, gambling and gaming, tobacco manufacturing and sales, hotels, weapons and defense, and real estate holding and development companies. Companies which are involved in any of the aforementioned activities are immediately excluded from the investable stock list. In addition, stocks of companies are financially screened to ascertain the (excessive) level of (interest-based) debt utilization, as well as interest-based income and expenses. In this context, stocks are screened based on the following ratios, that is, the ratio of total debt divided by trailing 24 -month average market capitalization, the ratio of the sum of a company's cash and interest-bearing securities divided by trailing 24-month average market capitalization, and the ratio of accounts receivables 
divided by trailing 24-month average market capitalization. For each of these financial ratios, the threshold allowed by Dow Jones is 33\%. In this regard, even for companies which have met the qualitative screening in terms of their business activities, they will be eventually classified as non-Sharia-compliant if any of the aforementioned financial ratios exceeds the threshold allowed (Engkuchik, 2016).

The DJIM index series currently encompasses more than 70 indices and continues to be the most comprehensive family of Islamic market indexes. In fact, DJIM played a significant role in introducing Sharia-compliant investment guidelines at global level. Since its first launch in 1999, the sector and financial screenings methodology employed have evolved. The Sharia supervisory board of it has revised the initial Sharia screening criteria from time to time to enable the formulation of an index. Recently the DJIM Sharia supervisory board has taken up market capitalization as a divisor to calculate debt, receivables and interest income ratios. The shift to employ this method was basically driven by the need to use a denominator that is inconsistent with the index market practice, since the sole aim of the creation an index is to trace the performance of the target market (Kamal, 2008 as cited in Htay et al., 2013). An initial screening process is carried out to screen industry sector compatible with sharia and will issue the business sector as opposed to the provision of religious covers which are moving in the alcohol industry, products related to pork, the conventional financial industry and certain entertainment service providers (entertainment gambling/casino, cinema, hotel, pornography, music). Manufacture of tobacco/cigarette and gun companies also includes industry issued from the Islamic index, although there is no strict prohibition in Islamic investment law. After the screening process is done, then it continues with the screening of financial ratios (Mulyaningsih, 2008 as cited in Shofawati, 2011). Sharia scholars have legitimized investment in companies with interest-based debt less than $33 \%$ of their equity. They have deduced this 33\%figure from the saying of the prophet (S.AW), 'one third is big or abundant'. Less than $33 \%$ would not be big or abundant and, hence tolerable, in the given circumstance (Obidullah, 2008 as cited in Htay et al., 2013).

\section{Conclusion}

The mechanism of stock screening according to the Fatwa DSN-MUI, the Kuala Lumpur Stock Exchange Islamic Index and the Dow Jones Islamic Market Index is based on two criteria, types of business activity or core activity screening and financial screening. Each of the indices begins the screening process by eliminating companies which are 
involved in any of the business activities or products that are contrary to sharia principles and then stocks of companies are financially screened to ascertain the stocks are screened based on the financial ratios according to the specification and parameter of each indices. Standardization of Islamic investment is very important to make Islamic investment screening more prudent and according to sharia compliance. Dow Jones Islamic Market Index and Fatwa DSN MUI, the Kuala Lumpur Stock Exchange Islamic Index are representative of the Standardization of Islamic investment screening in the capital market and which is suitable with sharia compliance. The Dow Jones Islamic Market Index is representative of the capital market of developed countries while Fatwa DSN MUI and the Kuala Lumpur Stock Exchange Islamic Index are a representative of the capital market in developing countries. The role of the Dow Jones Islamic Market Index is for the development of the Islamic capital market at the global and international level, while the role of Fatwa DSN MUI and the Kuala Lumpur Stock Exchange Islamic Index is for the development of the Islamic capital market at national and regional level. The similarities of each index to conduct screening is based on two criteria, consisting of business screening criteria and financial screening criteria, but there are differences between the indices, especially from the financial screening criteria specification and parameter.

\section{References}

[1] Ahmad, Zamri and Haslindar Ibrahim. 2002. A Study of Performance of the KLSE Syariah Index. Malaysion Management Journal 6 (182), 25-34 (2002)

[2] Engkuchik, Engku Ngah S. 2016. A Review of Securities Commission of Malaysia's Revised Shariah Stock-Screening Criteria. Journal of Islamic Banking and Finance June 2016, Vol. 4, No. 1, pp. 71-80

[3] FATWA DEWAN SYARI'AH NASIONAL NO:40/DSN-MUI/X/2003 Tentang PASAR MODAL DAN PEDOMAN UMUM PENERAPAN PRINSIP SYARIAH DI BIDANG PASAR MODAL

[4] https://us.spindices.com/index-family/shariah/dow-jones-islamic-market

[5] Htay, Sheila Nu Nu, Zafar Abedeen, Syed Ahmed Salman. Towards Standardization of Shari'ah Screening Norms and Practices. 2013. International Journal of Humanities and Social Science Invention ISSN (Online): 2319 - 7722, ISSN (Print): 2319 - 7714 www.ijhssi.org Volume 2 Issue 11 November. 2013 PP.23-30

[6] Peraturan Nomor II.K.1: Kriteria Dan Penerbitan Daftar Efek Syariah

[7] Nomor: Kep-180/BL/2009, 30 June 2009 
[8] Rahman, Azhar Abdul, Mohd Azlan Yahya and Mohd Herry Mohd Nasir. 2010. Islamic Norms For Stock Screening A Comparison Between The Kuala Lumpur Stock Exchange Islamic Index And The Dow Jones Islamic Market Index. International Journal of Islamic and Middle Eastern Finance and Management Vol. 3 No. 3, 2010 pp. 228-240

[9] Shaikh, Salman. 2010 Analysis of Stock Screening Principles in Islamic Mutual Funds Industry. Online at http://mpra.ub.uni-muenchen.de/19755/MPRA Paper No. 19755, posted 7. January 2010 09:22 UTC

[10] Shofawati, Atina. 2011. The Principles of Islamic Ethical Investment of The Islamic Capital Market. International Conference and Call for Paper. Universitas Negeri Jakarta

[11] Wan Zainal, Wan Arliza, Nawal Kasim, Nor Balkish Zakaria and Norazida Mohamed. 2016. Disputes And Resemblance: Comparative Analysis Of Shariah Advisory Committee Methodology And International Indices. Malaysian Accounting Review, Volume 15 No. 2, 2016 